\title{
CONCEPT OF FORM IN THE FILM DILAN 1990
}

\author{
Naafi Nur Rohma \\ Institut Sains dan Teknologi Terpadu Surabaya, Indonesia \\ E-mail: naafi@stts.edu
}

\begin{abstract}
The Dilan 1990 is an adaption film that chronicles the romance of high school teenagers in the 1990s. This film ranked first in terms of viewership in 2018. The allure of this film that warrants further analysis is its shape notion. This study aims to analyze the Dilan 1990 film's notion of form. This qualitative descriptive study analyzes data using the form concept methodology created by David Bordwell and Kristin Thompson. The findings indicate that the film's forms and processes are extremely complicated. The constructed elements are connected in such a way that they can excite the audience's emotions, most notably their expectations.
\end{abstract}

Keywords: Film, Dilan 1990, and concept of forms

\section{ABSTRAK}

Film Dilan 1990 merupakan film adaptasi yang bercerita tentang romansa remaja SMA era 90-an. Film ini menduduki peringkat teratas dengan jumlah penonton sepanjang tahun 2018. Daya tarik film yang ingin dikaji ini adalah konsep bentuknya. Tujuan dari penelitian ini untuk mengetahui konsep bentuk dalam film Dilan 1990. Dalam penelitian deskriptif kualitatif ini metode analisisnya menggunakan pendekatan konsep bentuk yang dikembangkan oleh David Bordwell dan Kristin Thompson. Hasil penelitian menunjukkan bahwa bentuk dan sistem yang bekerja pada film sangat kompleks. Elemen-elemen yang dibangun memiliki keterkaitan satu dengan yang lain, sehingga dapat membangun emosi penonton, khususnya menstimulus ekspektasi penonton.

Kata kunci: Dilan 1990, dan konsep bentuk

\section{PENDAHULUAN}

Film Dilan 1990 menjadi sebuah fenomena dalam industri perfilman di Indonesia. Hal ini dikarenakan film adaptasi novel karya Pidi Baiq karya sutradara Fajar Bustomi mampu menembus jumlah penonton dengan angka di atas 6 juta sepanjang tahun 2018 (Yulistara, 2018) dan berhasil meraih penghargaan Piala Citra pada Festival Film Indonesia tahun 2018 (http://filmindonesia.or.id/). Selain itu, film yang berlatar era tahun 1990 yang diperankan oleh aktor lqbal Ramadhan sebagai Dilan dan aktris Vanessa Pricilla sebagai Milea ini juga viral pada tahun 2018.

Viral tersebut terkait dengan adanya fenomena meme-meme dialog romantis yang diambil dari film Dilan 1990. Meme sudah tidak asing lagi bagi kalangan yang aktif bermain media sosial. Meme muncul sebagai respons atas beragam kejadian terkini yang sedang hangat dibicarakan (Fitri, 2018).

Salah satu meme berisi dialog Dilan dengan Milea pada adegan ketika Dilan 
menelepon Milea di telepon umum koin: "Jangan rindu berat. Biar aku saja." Hal ini membuktikan bahwa ada pengaruh peran dari bentuk dan pengalaman penonton yang bekerja pada film Dilan 1990.

Dari kutipan dialog film Dilan 1990 di atas juga tampak bahwa film diciptakan dengan konsep, bukan asal diproduksi. Seperti dikemukakan Mastura Muhammad bahwa "Filem tidak dihasilkan secara rawak (random). Filem dihasilkan di bawah satu sistem yang lengkap dan merupakan satu siri yang tersusun“ (Muhammad, 2006).

Adapun tujuan dari penelitian ini adalah untuk mengetahui konsep bentuk film Dilan 1990 dengan analisis interpretasi memakai teori konsep bentuk yang dikembangkan oleh David Bordwell dan Kristin Thompson.

\section{TINJAUAN PUSTAKA}

Buku Film Art an Introduction menjelaskan bahwa pengalaman di dalam seni menawarkan penonton atau penikmat seni untuk dapat ikut terlibat di dalamnya (Bordwell \& Thompson, 2008). Artinya, di dalam seni mampu memberikan sesuatu yang dapat menstimulus penonton untuk ikut terhanyut di dalam karya seni yang dibuat atau bahkan dapat mempengaruhi penonton. Hal ini berlaku untuk karya seni apapun termasuk karya film, yang sering disebut dengan kedalaman film atau keterhanyutan, contohnya adalah ketika pembaca ikut terhanyut ke dalam sebuah bacaan buku ketika sedang membaca buku. Sehingga, ketika orang tidak selesai membaca buku, dia akan berkata "Saya tidak bisa ikut mendalaminya." Hal tersebut dapat diartikan bahwa orang tersebut tidak mampu merasakan atau mengerti apa yang ingin disampaikan si penulis.

Hal ini berlaku pula dalam film Dilan 1990. Semua cara bicara, tingkah laku, latar belakang yang disampaikan di dalam film Dilan 1990 melibatkan indera, perasaan, dan pikiran penonton ke dalam sebuah proses. Proses tersebut mempertajam ketertarikan dan mempererat keterlibatan penonton, dan menggiringnya untuk terus mengikuti alur cerita. Hal itu dapat terjadi dikarenakan filmmaker telah membuat sebuah pola di dalam filmnya. Seniman mendesain karyanya dengan memberikan bentuk ke dalam filmnya sehingga penonton dapat memiliki pengalaman yang terstruktur.

Oleh sebab itu, bentuk menjadi sangat penting di dalam sebuah karya seni dan media apapun termasuk film. Hal itu dikarenakan menjadi sebuah cara untuk memahami objek seni salah satunya adalah film Dilan 1990.

Bordwell dan Thompson dalam buku Film Art an Introduction menjelaskan bahwa ide bentuk artistik telah dimiliki oleh para pemikir filosofis, seniman dan kritikus selama berabad-abad yang lalu (Bordwell \& Thompson, 2008). Adapun konsep bentuk, antara lain: bentuk sebagai sistem; 
bentuk versus konten; bentuk dan perasaan; serta bentuk dan makna.

\subsection{Bentuk sebagai Sistem}

Bentuk artistik merupakan sebuah pemikiran yang baik yang berkaitan dengan orang yang menonton sebuah pertunjukan, membaca sebuah novel, mendengarkan music, dan menonton film. Pada dasarnya persepsi dari semua fase tersebut adalah sebuah aktivitas. Ketika orang sedang berjalan menyusuri sebuah jalan, orang akan melakukan aktivitas memindai area sekelilingnya dan menangkap aspek-aspek yang menonjol seperti wajah teman yang berjalan bersama, tanda-tanda hujan, atau orang-orang yang nampak mencurigakan. Pikiran tidak pernah diam. Hal ini terus berlangsung untuk menemukan sebuah keteraturan dan makna yang bertujuan untuk orang tersebut dapat beristirahat dalam pola kebiasaan.

Ketika pembaca telah selesai membaca novel, isi dari novel itu selalu meninggalkan imajinasi kepada pembacanya. Begitu juga saat penikmat musik sedang mendengarkan musik, setiap musik menjelaskan kepada penikmatnya tentang melodi yang dimainkan dalam musik tersebut melalui nada-nada atau cord-nya. Begitu juga dengan film, setiap film memberikan isyarat kepada penonton untuk menghubungkan sekuen satu dengan sekuen yang lain untuk menjadi satu kesatuan yang besar atau yang lebih kompleks, sehingga penonton mampu menarik makna yang di dalam film atau musik tersebut. Hal penting yang perlu diketahui adalah cara kerja dari film supaya dapat meninggalkan isyarat kepada penonton sehingga penonton dapat menarik makna dalam film tersebut.

Sebuah novel hanyalah kata-kata yang berada di atas kertas, sebuah lagu hanyalah getaran akustik, sebuah film hanyalah pola terang dan gelap. Objek tidak melakukan apapun. Oleh sebab itu, objek dan orang yang mengalaminya saling bergantung. Hal tersebut menuntut orang untuk melakukan sebuah aktivitas atau melakukan permainan. Tanpa melakukan itu, maka karya seni hanya merupakan artefak mati. Seni lukis dapat menggunakan warna, garis, ataupun teknik untuk mengundang penonton membayangkan ruang yang digambarkan atau mengarahkan pandangan mata penonton ke komposisi tertentu. Penulis cerita dapat menggunakan kata-kata yang ditulisnya untuk dirangkai menggunakan kalimat-kalimat terstruktur, sehingga mengundang minat pembaca dengan membayangkan setiap adegan yang dibuat melalui kalimatnya.

Bordwell dan Thompson (2008) menjelaskan bahwa seni tidak dapat bekerja sendiri melainkan seni selalu melibatkan pendukungnya, yaitu berupa elemen-elemen bentuk sehingga seni mampu menyelipkan isyarat secara implisit 


\section{CAPTURE}

maupun eksplisit di dalamnya sebagai tujuan dari si pembuat karya kepada penikmatnya. Penonton atau penikmat dapat membaca isyarat-isyarat yang dipertunjukkan dalam sebuah film melalui elemen-elemen bentuk. Perlu diketahui bahwa, elemen-elemen itu tidaklah disusun secara acak dan mudah, tetapi elemen itu dibentuk berdasarkan sistem. Masingmasing elemen memiliki fungsi dan pengaruh yang berbeda-beda. Ibarat tubuh manusia, salah satu sistemnya adalah hati, jika hati berhenti bekerja, maka hal itu akan menimbulkan efek, yaitu membuat bagianbagian yang lain mengalami bahaya karena pengaruh dari ketidakfungsian hati.

Seperti seni yang lain, film memiliki bentuk. Melalui bentuk dapat diketahui secara keseluruhan hubungan sistem antara elemen-elemen melalui film. Broadwell \& Thompson (2008) juga mempertimbangkan bagaimana pengaruh peran bentuk dan gaya dalam pengalaman penonton.

\subsection{Bentuk versus Konten}

Orang sering berpikir bahwa "bentuk" memiliki arti yang berkebalikan dengan sesuatu yang bernama "konten". Hal ini mengimplikasikan bahwa sebuah karya puisi, novel, ataupun film adalah sebuah wadah. Bentuk luar atau wadah dapat mengandung sesuatu yang dapat disimpan, diambil, dan diletakkan di dalam wadah seperti ember atau cangkir.
Bordwell \& Thompson (2008) menolak atas asumsi tersebut. Hal ini dikarenakan jika sebuah karya seni film merupakan sistem total dari keseluruhan film, maka tidak ada yang namanya dalam maupun luar. Filmmaker membuat isyaratisyarat tertentu di dalam filmnya yang bertujuan untuk membingkai harapanharapan tertentu kepada penonton. Sehingga, penonton dapat menarik kesimpulan atas isyarat-isyarat yang telah dibuat di dalam karya film tersebut. Penampil dari isyarat-isyarat tersebut menghubungkan elemen-elemen tertentu secara dinamis. Konsekuensinya, subjek yang mengalaminya dan ide menjadi berbeda dari apa yang telah dikerjakan.

Salah satu bentuk cara mempengaruhi penonton adalah dengan menciptakan bahwa "semuanya ada di sana". Film menjadi tampak memuaskan ketika suatu tokoh yang pergi, kembali lagi pada satu jam berikutnya, hal itu menunjukkan bahwa film memiliki hukum atau aturan yang mengatur sendiri sistemnya. Selain itu, bentuk karya seni juga menciptakan semacam keterlibatan penonton.

Dalam kehidupan sehari-hari orang dengan praktis memahami hal-hal yang berada di sekitar. Tetapi hal-hal tersebut tidak dapat terjadi ketika penonton sedang menonton film. Penonton melihat sesuatu yang berbeda dari yang ada di dalam kehidupan mereka. Dalam kehidupan 
sehari, ketika orang melihat temannya terjatuh, maka akan bergegas untuk menolongnya. Namun, berbeda dengan film komedi Charlie Chaplin, jika penonton disuguhkan sebuah adegan orang terjatuh, maka itu membuat penonton tertawa. Hal itu merupakan sebuah aktivitas pembuatan film yang membingkai gambar dengan menciptakan cara pandang tertentu.

Asumsi bahwa "A" adalah huruf pertama. Kemudian akan muncul pertanyaan, apa yang akan terjadi berikutnya? "A" merupakan sebuah isyarat huruf pertama dari sebuah huruf seri Alfabet, pembaca atau penonton telah membuat sebuah formal hipotesis, kemungkinan besar berikutnya adalah $\mathrm{B}$. Ekspektasi penonton telah terkonfimasi. Pertanyaan berikutnya muncul, setelah $A B$ terkonfirmasi, maka pembaca atau penonton akan berasumsi bahwa berikutnya adalah $\mathrm{C}$. Tetapi, bentuk tidak selalu mengikuti ekspektasi penonton, karena bisa jadi adalah ABA dan bukan $A B C$ seperti ekspektasi penonton. Bagian itu letak kejutan-kejutan kecil yang dibuat oleh seorang pembuat film kepada penonton. Pembuat film memiliki sistem tersendiri untuk memberikan kejutan kepada penontonnya.

\subsection{Bentuk dan Perasaan}

Emosi memainkan peran besar pada pengalaman penonton atau penikmat film. Ada perbedaan yang mendasar mengenai peran emosi, yakni perbedaan antara peran emosi yang diwakili dalam karya seni, adegan di dalam film, atau emosi sebagai respons atas karya seni. Misalnya, dalam film terdapat sebuah adegan menyedihkan yang diwakili oleh peran aktor sedang menangis, maka emosi menyedihkan terwakili pada film tersebut. Sebaliknya, jika penonton tertawa saat melihat adegan yang menyakitkan, maka emosi hiburan dirasakan oleh penonton. Emosi yang telah diwakilkan dalam film berinteraksi dengan sebagian dari keseluruhan sistem film. Sebuah kesedihan di dalam film merupakan respons karakter terhadap berita buruk. Ekspresi licik karakter dapat mendorong penonton melihat sisi jahat karakter dalam film tersebut.

Semua emosi yang ada dalam film tampak terkait satu sama lain melalui bentuk film itu. Respons emosional penonton terhadap film juga terkait dengan bentuk. Hal terpenting dalam memainkan emosi adalah aspek dinamis dari bentuk yang melibatkan perasaan penonton. Misalnya, sebuah ekspektasi yang muncul dalam benak penonton yang menstimulus munculnya emosi untuk memiliki harapan tentang "apa yang akan terjadi selanjutnya". Adegan yang dibuat dalam film tentang keterlambatan pemenuhan harapan tersebut dapat memicu ketegangan menghasilkan kecemasan atau rasa simpati. Maka, dalam benak penonton 
akan timbul perasaan atau pertanyaan "Apa detektif akan menemukan penjahat? Apakah superhero itu akan mati atau tetap hidup? Apakah laki-laki itu akan mendapatkan perempuan?" Jika harapanharapan yang telah muncul dalam benak penonton itu kemudian filmmaker memenuhi harapan-harapan itu, maka yang terjadi adalah dapat menghasilkan perasaan puas atau lega. Misalnya, detektif itu dapat memecahkan misteri; superhero itu tetap hidup meskipun dalam keadaan tidak sehat; anak laki-laki mendapatkan perempuan. Selain itu, harapan dan rasa ingin tahu tentang materi yang disampaikan dalam film dapat menghasilkan rasa minat kepada penonton yang lebih dalam atau tajam. Misalnya, dalam adegan film akan memunculkan pertanyaan "jadi dia bukan detektif? Ini bukan kisah cinta?" Semua kemungkinan itu dapat terjadi di dalam film.

Bordwell dan Thompson (2008) mengatakan bahwa tidak ada resep untuk meramu sebuah novel atau film yang dapat menghasilkan respons emosional yang "benar" dikarenakan semua itu adalah masalah konteks, yaitu sistem tertentu yang merupakan bentuk keseluruhan dari karya seni. Emosi yang dirasakan oleh penonton akan muncul dari totalitas hubungan formal yang penonton rasakan dalam film tersebut. Inilah salah satu alasan mengapa pembuat film harus berusaha memperhatikan sebanyak mungkin hubungan formal dalam film. Hal ini dikarenakan semakin banyak persepsi pembuat film, maka respons yang dihasilkan oleh penonton akan semakin dalam dan kompleks. Hubungan antara perasaan yang diwakili dalam film dan yang dirasakan oleh penonton bisa sangat rumit. Jadi, emosi yang diwakilkan di dalam film serta respons penonton bergantung pada konteks yang diciptakan oleh bentuk.

\subsection{Bentuk dan Makna}

Seperti halnya dengan emosi, makna merupakan hal penting bagi pengalaman terkait dengan karya seni. Penonton secara konstan 'menguji' karya seni untuk mendapatkan sesuatu yang lebih bermakna dari apa yang telah diungkapkannya.

Bordwell dan Thompson (2008) membicarakan makna menjadi 4 jenis, yakni:

\section{1). Referential Meaning}

Makna jenis ini lebih fokus pada ringkasan plot. Hal ini tergantung kepada kemampuan penonton untuk mengidentifikasinya. Penonton memiliki kemampuan untuk menangkap isyarat yang berbeda-beda dalam film.

\section{2). Explicit Meaning}

Seperti referential meaning, makna eksplisit berfungsi dalam bentuk keseluruhan film. Keduanya didefinisikan oleh konteks. Ketika ada seseorang yang bertanya tentang poin dari sebuah film, 
maka orang yang menjawab kemungkinan akan menyebutkan sebuah judul film, kemudian me-review dari apa yang telah dilihatnya.

Seperti perasaan, makna lahir dari bentuk yang dinamis. Keduanya bermain pada bagiannya masing-masing dengan elemen lain untuk membuat sistem keseluruhan. Maka, keseluruhan sistem film lebih besar daripada makna eksplisit yang ditemukan di dalam film. Daripada bertanya, "Apa makna film ini?" penonton dapat bertanya, "Bagaimana semua makna dalam film itu berhubungan satu sama lain?"

\section{3). Implicit Meaning}

Makna implisit lebih terlihat abstrak dibandingkan dengan dua jenis makna sebelumnya. Itu melampaui apa yang dinyatakan secara eksplisit dalam film. Beberapa penonton mungkin mengagumi sebuah film, dikarenakan film menyampaikan pesan yang mendalam atau relevan dengan kehidupan nyata. Tetapi hal tersebut justru sering keliru, artinya mereka memecah film menjadi bagian-bagian isi atau makna dan bentuk atau alur atau konten. Padahal kualitas makna implisit (tersirat) dapat mengarah pada konsep yang luas, yang sering disebut dengan tema.

Bordwell dan Thompson (2008) menyarankan bahwa ketika mencari makna implisit dari sebuah film, tidak boleh meninggalkan fitur-fitur khusus dari sebuah film. Hal ini bukan berarti bahwa penonton tidak boleh menafsirkan film, tetapi harus berusaha untuk menafsirkan secara tepat dengan melihat bagaimana makna tematis setiap film berdasarkan oleh sistem keseluruhan film. Dalam sebuah film, makna baik eksplisit maupun implisit sangat bergantung erat pada hubungan antara narasi dan gaya. Film style merupakan objek yang paling empiris dalam film (Eisenstein 1957; Patawari, 2019).

Interpretasi dapat dilihat sebagai sebuah analisis formal yang berusaha mengungkap makna tersirat sebuah film. Makna-makna tersebut harus terus diuji dengan menempatkannya di dalam tekstur konkret dari keseluruhan film.

\section{4). Symptomatic Meaning}

Seperti ketiga jenis makna yang telah disampaikan sebelumnya, makna symptomatic lebih abstrak dan umum. Makna jenis ini lebih pada ideologi masingmasing penonton dalam mengasumsikan film tersebut berdasarkan fenomena sosial yang terjadi di dalam masyarakat.

Pembahasan makna simptomatik mengingatkan bahwa makna referensial, eksplisit ataupun implisit yang sebagian besar merupakan fenomena sosial. Banyak makna film yang pada akhirnya merupakan hasil dari ideologis. Hal ini dikarenakan muncul dari sistem kepercayaan dan kebudayaan tertentu tentang dunia, misalnya keyakinan agama, pendapat 


\section{CAPTURE}

politik, konsepsi tentang rasa atau jenis kelamin atau kelas sosial tertentu, bahkan gagasan kehidupan manusia yang mendalam. Hal itu menjadi kerangka acuan ideologis manusia. Manusia hanya perlu membandingkan ideologinya sendiri dengan kelompok atau budaya atau era lain untuk melihat bagaimana secara historis dan sosial dari pandanganpandangan itu.

Film seperti karya seni yang lain dapat diperiksa makna simptomatiknya. Meskipun kualitas abstrak dan umum dari makna semacam itu dapat membawa jauh dari bentuk konkret dari film tersebut. Sebuah film memberlakukan makna ideologis melalui sistem formalnya yang khusus dan unik.

Terkadang pembuat film mengarahkan penonton menuju makna tertentu, tetapi terkadang pula penonton tidak menemukan makna yang tidak diinginkan oleh pembuat film. Oleh sebab itu, perlu menyelidiki signifikasi karya seni (film) dalam beberapa tingkatan, yakni makna referensial, eksplisit, implisit dan simptomatik. Oleh sebab itu, dalam menganalisis sebuah film, harus menyeimbangkan antara sistem konkret dengan keinginan untuk memberikan arti yang lebih luas.

\section{METODE}

Penelitian ini menggunakan jenis penelitian deskriptif kualitatif, khususnya memakai pendekatan Konsep Bentuk yang dikembangkan oleh David Bordwell dan Kristin Thompson. Pendekatan itu dipakai untuk menganalisa konsep bentuk pada film Dilan 1990.

Teknik pengumpulan data menggunakan Purposive Sampling, di mana hanya adegan pengantar film yang dikaji. Adapun metode pengumpulan data memakai telaah dokumen dan studi pustaka. Prosedur pengolahan data yang dilakukan adalah reduksi data, sajian data, pengambilan kesimpulan dan saran. Analisis data dilakukan dengan interpretasi konsep bentuk dalam film Dilan 1990.

\section{PEMBAHASAN}

\subsection{Film Dilan 1990}

Spesifikasi film yang menjadi objek kajian ini adalah:

$\begin{array}{ll}\text { Produser } & \text { : Ody Mulya Hidayat } \\ \text { Sutradara } & \text { : Fajar Bustomi, Pidi Baiq } \\ \text { Penulis } & \text { : Pidi Baiq, Titien } \\ & \text { Wattimena } \\ \text { Pemeran } & \text { : Iqbal Ramadhan, } \\ & \text { Vanesha Prescilla } \\ \text { Tanggal Edar } & \text { : Kamis, 25 Januari } 2018 \\ \text { Sinopsis } & :\end{array}$

Film Dilan 1990 merupakan sebuah kisah romansa remaja era 1990 . Kisah ini menceritakan remaja SMA tahun 1990 bernama Dilan dan Milea. Film ini diawali dengan Milea yang menceritakan kisah masa lalunya bersama Dilan, seseorang yang pernah dicintainya di masa SMA.

Kisah Dilan dan Milea berawal dari perkenalan yang tidak biasa di sebuah 
SMA di Bandung. Milea merupakan murid SMA pindahan dari Jakarta ke Bandung. Perkenalan unik yang dilakukan oleh Dilan kepada Milea membuat Milea kenal Dilan lebih jauh.

Dilan merupakan sosok yang pintar, baik dan romantis. Dilan juga merupakan ketua geng motor terkenal di Bandung, sehingga sering disebut dengan Panglima Tempur. Sebagai Panglima Tempur, Dilan memiliki cara yang sendiri untuk dapat mendekati Milea. Salah satu cara yang dilakukannya kepada Milea bukan cara seperti memberikan bunga atau kata-kata romantic, tetapi lebih kepada sebuah aksi yang unik. Salah satu aksinya adalah dengan cara meramal Milea ketika pertama kali bertemu.

Dilan berkata kepada Milea "Aku ramal, nanti kita akan bertemu di kantin". Meskipun pada akhirnya ramalan tersebut meleset karena Milea tidak pergi ke kantin. Aksi Dilan kepada Milea terlihat sederhana, tetapi dapat membuat Milea tersenyum dan kemudian membuat perlahan menaruh perhatiannya kepada Dilan, padahal Milea telah memiliki pacar di Jakarta bernama Beni.

Suatu waktu Milea memutuskan Beni, pacarnya. Akibat perbuatan Beni yang kasar kepada Milea. Beni bahkan menampar Milea. Semenjak putusnya hubungan Beni dengan Milea, membuat Milea semakin dekat dengan Dilan.

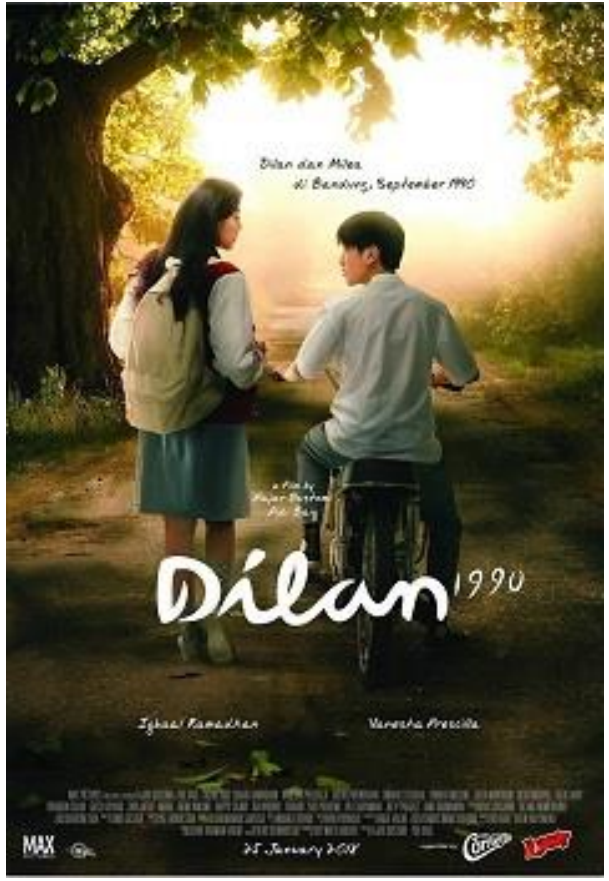

Gambar 1. Poster film Dilan 1990 (Sumber: Picture play Dilan 1990 Review. https://pictureplayblog.wordpress.com/2018/01/25/dila n-1990-review-adaptasi-verbatim-dengan-maknayang-minim/diakses 4 Februari 2019)

\subsection{Adegan Film Dilan 1990}

Konsep bentuk dalam film ini dipaparkan dalam 2 tahap. Tahap pertama, mendeskripsikan adegan yang tampak pada potongan adegan, yaitu pengambilan gambar, kostum, dan setting. Tahap kedua, menganalisis potongan adegan berdasarkan konsep bentuknya. Berikut ini merupakan potongan adegan dari film Dilan 1990.

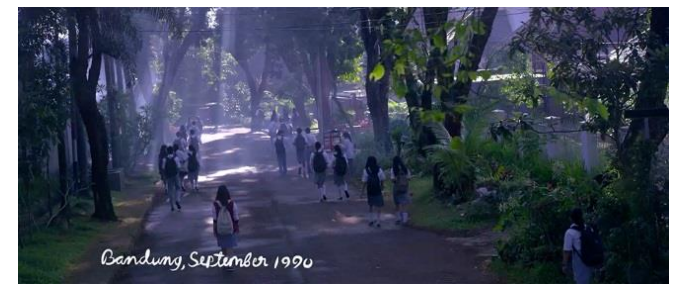




\section{CAPTURE}
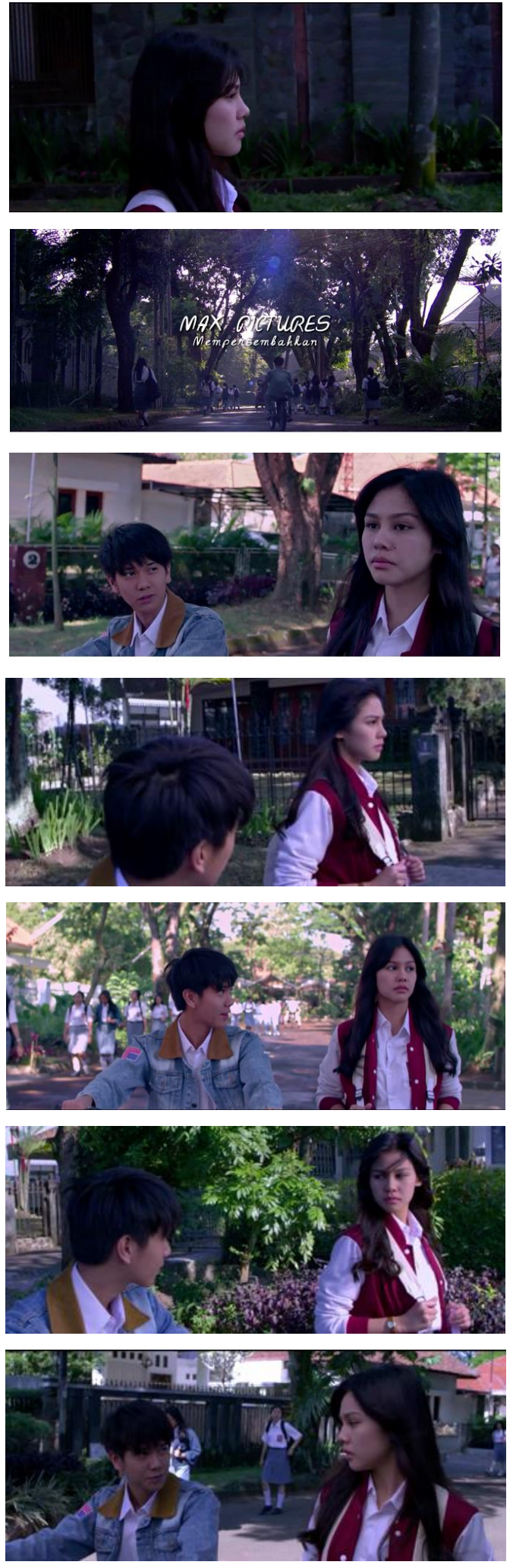
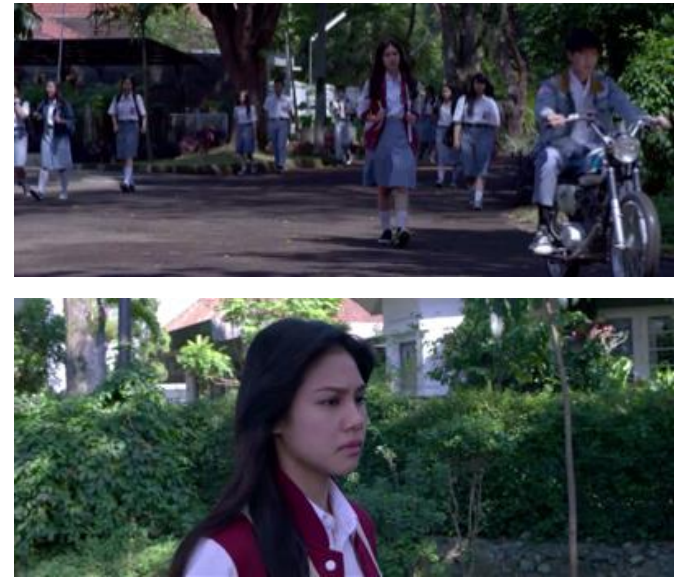

Gambar 2. Perkenalan Dilan dan Milea

(Sumber: Film Dilan 1990, timecode 0.48-1.39)

Deskripsi adegan di atas sebagai berikut.

a). Pertama ( Timecode: 00.48)

Kamera pada posisi high angle dan berukuran long shot serta pergerakannya track right secara perlahan. Gambar menampilkan suasana pada pagi hari, di mana tampak pelajar sedang dalam berangkat sekolah. Lebih jauh, ditunjukkan beberapa orang yang berjalan memakai seragam putih dan abu-abu. Salah satunya adalah Milea yang memakai jaket warna merah dan berambut panjang hitam terurai. Adegan ini diiringi sebuah music backsound.

b). Kedua (Timecode: 00.54)

Kamera berada pada posisi eye level, berukuran medium close up, dan pergerakan kameranya tracking mengikuti Milea dari arah samping. Gambar memperlihatkan Milea dari samping sedang berjalan menatap ke depan yang diiringi sebuah music backsound.

c). Ketiga (Timecode: 01.00) 
Kamera berada pada posisi eye level, berukuran long shot, dan kamera diam atau tidak melakukan pergerakan. Pada adegan terlihat Dilan masuk dari arah kanan (in frame) memakai jaket jeans dengan mengendarai motor 90-an dan mendekat ke arah Milea yang sedang berjalan. Adegan diiringi sebuah music backsound.

d). Keempat (Timecode: 01.06)

Kamera berada pada posisi eye level Milea yang sedang berjalan. Pada awalnya kamera berukuran medium close up, kemudian Milea melakukan pan left ke arah datangnya Dilan, sehingga kamera berukuran two shot medium close up. Gambar menunjukkan Dilan datang mendekati Milea. Pergerakan kamera mengikuti arah jalan Milea dan Dilan yakni tracking. Dilan berkata kepada Milea, "Selamat pagi". Milea menoleh ke arah Dilan dengan raut wajah yang tidak ramah lalu kembali menatap lurus ke depan sambil menjawab sapaan Dilan, "Pagi". Adegan juga diiringi music backsound.

e). Kelima (Timecode: 01.11)

Kamera berada pada posisi eye level dan over shoulder Dilan yang sedang mengendarai motor. Pada gambar tampak kamera berukuran medium shot, di mana Milea yang berjalan di sisi kiri Dilan yang berkendara. Kamera bergerak tracking mengikuti Dilan dan Milea. Dilan menatap Milea, kemudian bertanya, "Kamu Milea, ya?". Milea tampak menoleh ke arah Dilan, kemudian menjawab dengan ragu, "Iya". Music backsound mengiringi adegan tersebut.

f). Keenam (Timecode: 01.18)

Kamera berada pada posisi eye level merekam Dilan dan Milea dari arah depan dengan ukuran medium shot, sehingga mereka tampak sedang berjalan dan mengendarai motor beriringan. Dilan bertanya kepada Milea yang masih tampak cuek, "Boleh aku ramal?". Milea balik bertanya, "Ramal?" dengan ekspresi heran. Dilan menjawab dengan yakin, "Iya. Aku ramal nanti siang kita akan bertemu di kantin." Gambar juga diiringi music backsound.

g). Ketujuh (Timecode: 01.22)

Kamera berada pada posisi eye level dan over shoulder Dilan yang sedang mengendarai motor. Kamera berukuran medium shot merekam Milea yang berjalan di sisi kiri Dilan yang sedang berkendara, tampak Dilan menatap Milea. Kemudian, Milea menatap Dilan tanpa menjawab atau berkata apa-apa. Kamera melakukan pergerakan tracking mengikuti Dilan dan Milea dengan iringan music backsound. h). Kedelapan (Timecode: 01.30)

Kamera berada pada posisi eye level dari Milea mengarah ke Dilan yang sedang mengendarai motor. Kamera berukuran medium two shot menggambarkan Milea yang berjalan di sisi kiri Dilan. Dilan menatap Milea lalu menawarkan tumpangan dengan mengayunkan 


\section{CAPTURE}

kepalanya ke arah motor belakang. "Mau ikut?". Milea menjawab dengan menggeleng, "Nggak, makasih". Dilan berkata, "Tapi suatu hari nanti kamu pasti akan naik motorku. Percayalah. Duluan ya.". Dilan melaju out frame. Kamera melakukan pergerakan tracking mengikuti Dilan dan Milea dengan iringan music backsound.

i). Kesembilan (Timecode: 01.37)

Gambar tampak kamera long shot dan posisi diam eye level. Dilan mengendarai motornya mendahului Milea yang sedang berjalan. Dilan kembali out frame. Gambar diiringi music backsound.

j). Kesepuluh (Timecode: 01.39)

Kamera berada pada posisi eye level, berukuran medium close up, dan pergerakan kamera tracking mengikuti Milea dari arah samping. Pada gambar tampak Milea dari samping berjalan menatap ke arah Dilan yang telah pergi sambil mengkerutkan kening, lalu menggelengkan kepala. Music backsound mengiringi adegan tersebut.

\subsection{Konsep Bentuk Film Dilan 1990}

\subsubsection{Bentuk sebagai Sistem}

Film Dilan 1990 adalah bentuk sebagai sistem yang menghubungkan antara elemen satu dengan elemen yang lainnya. Adapun elemen-elemen yang dihubungkan adalah elemen cerita, visual ataupun audio yang meliputi: narasi, miseen-scene, dan audio. Melalui adegan pada
Gambar 2 dapat diketahui tentang awal mula Milea dan Dilan bertemu. Penonton dapat mengetahui setting cerita terjadi di tahun 1990. Hal itu ditunjukkan dengan tata artistiknya, seperti model jaket jeans, model rambut Milea, model motor Dilan, suasana jalan masih asri dengan banyak pepohonan besar. Selain itu, ada juga becak model tahun 1990 yang berjalan dari arah yang berlawanan.

Inti pada Gambar 2 adalah Dilan mendekati Milea sebagai murid baru yang tampak cuek kepadanya. Dilan menggunakan trik meramal untuk menarik perhatian Milea. Ketertarikan Milea tampak ketika Dilan ingin meramalnya. Milea bertanya dengan ekspresi wajah yang keheranan "ramal?". Meskipun tampak tertarik, tetapi Milea masih bersikap cuek kepada Dilan dengan menolak tawaran Dilan untuk membonceng motornya. Sikap percaya diri Dilan kepada Milea bahwa suatu saat nanti Milea akan naik motornya membuat Milea tidak habis pikir dan justru malah hal itu membuatnya merasa Dilan itu aneh.

\subsubsection{Bentuk versus Konten}

Ketika penonton disajikan adegan ketika Dilan ingin meramal Milea. Dilan berkata, "Iya. Aku ramal nanti siang kita akan bertemu di kantin." Dialog ini menjadi salah satu konsep bentuk versus konten. Dialog yang dimunculkan oleh tokoh Dilan akan membentuk asumsi penonton bahwa 
nanti Dilan akan bertemu dengan Milea di kantin sekolah setelah adegan Gambar 2. Penonton secara otomatis bertanya "Apakah ramalan Dilan benar? Apakah Dilan dan Milea akan bertemu di kantin sekolah pada adegan berikutnya?" Penonton telah membuat sebuah formal hipotesis, kemungkinan besar berikutnya adalah Dilan akan bertemu dengan Milea di kantin, yang ternyata hipotesis penonton tidak terkonfirmasi pada adegan berikutnya. Dilan dan Milea ternyata tidak bertemu di kantin, karena Milea menolak untuk ke kantin. Ini merupakan kejutankejutan kecil yang dibuat oleh filmmaker untuk penonton supaya penonton penasaran dan bertanya-tanya.

Tidak hanya itu, dialog berikutnya tampak Milea menolak tawaran Dilan untuk membonceng motornya, Dilan berkata dengan percaya diri, "Tapi suatu hari nanti kamu pasti akan naik motorku. Percayalah. Duluan ya". Berdasarkan dialog Dilan tersebut, penonton akan kembali bertanyatanya, "Apakah nanti Milea akan membonceng motor Dilan?" Penonton membutuhkan konfirmasi atas pertanyaan yang dimunculkan sebagai akibat dari dialog yang dilontarkan Dilan tersebut. Di situlah sistem kerja filmmaker untuk membuat penonton mendapatkan kejutankejutan dari film yang ditontonnya.

\subsubsection{Bentuk dan Perasaan} Emosi berperan penting dalam sebuah film. Hal ini juga ditunjukkan pada adegan pengantar film Dilan 1990, yakni oleh tokoh Dilan yang berperan sebagai siswa lama di sekolah tersebut. Tampak sangat jelas bahwa dia melakukan pendekatan kepada Milea, siswa baru yang cantik. Pendekatan itu dilakukan dengan cara yang aneh. Keanehan itu ditunjukkan dengan dialog-dialog Dilan kepada Milea. Bukan. Dilan meminta nomor atau memperkenalkan dirinya tetapi malah meramal Milea. Penonton dapat membayangkan jika dialog tersebut terjadi di dunia nyata pasti terasa sangat menggelikan. Emosi kegelian penonton diwakili oleh karakter Milea, ketika menatap Dilan dengan menunjukkan ekspresi raut wajah yang aneh. Dari adegan tersebut menunjukkan bahwa adegan tersebut telah melibatkan perasaan penonton.

Dialog-dialog Dilan tentang ramalan bertemu Milea membuat ekspektasi yang muncul dalam benak penonton yang menstimulus munculnya emosi untuk memiliki harapan tentang "apakah mereka akan bertemu di kantin", "apakah Milea akan membonceng motor Dilan?". Pemenuhan harapan-harapan yang terlambat, misalnya adegan berikutnya ternyata tidak bertemu di kantin, tetapi bertemu di rumah Milea. Hal itu menstimulus penonton untuk semakin memunculkan rasa minat yang mendalam terhadap adegan-adegan selanjutnya. Adegan Gambar 1 terlihat bahwa 


\section{CAPTURE}

hubungan yang kompleks antara hubungan bentuk dan perasaan sangat mempengaruhi respons penonton. Filmmaker sangat memperhatikan hubungan tersebut, melalui setiap dialog yang diucapkan dari tokoh Dilan. Pemenuhan ekspektasi penonton yang terlambat dapat membangun emosi penoton yang melihatnya.

\subsubsection{Bentuk dan Makna}

Selain bentuk dan perasaan, berikutnya adalah bentuk dan makna. Keseluruhan sistem yang dibangun dalam film Dilan 1990 tampak pada Gambar 2. Gambar tersebut memiliki hubungan antara konten yang dibangun, emosi yang dibangun, dan makna yang akan muncul sebagai akibat dari keseluruhan sistem. Berikut ini makna yang muncul.

\section{1). Referential Meaning}

Film Dilan 1990 merupakan film anak remaja SMA di era 1990. Film ini berlatar belakang (setting) di Bandung. Dilan adalah seorang siswa SMA yang ikut dalam geng motor di Bandung. Milea adalah siswa pindahan dari Jakarta ke Bandung. Dilan mendekati Milea dengan cara yang tidak biasa. Hal ini membuat Milea jatuh cinta kepada Dilan, tetapi hubungan keduanya dihalangi oleh Beni, pacar Milea sejak Milea di Jakarta. Di akhir cerita Mile dan Dilan pun mengumumkan hari jadi hubungan mereka dengan hal yang tidak biasa pula, yakni seperti proklamasi dan menggunakan tanda tangan bermaterai.

2). Explicit Meaning

Secara eksplisit makna yang terbentuk dari Gambar 2 adalah kisah awal mula pendekatan Dilan kepada Milea di tahun 1990. Secara ekspilit gambar tersebut menunjukkan bahwa Dilan adalah anak orang berkecukupan yang ditunjukkan dengan kepemilikan motor di tahun 1990. Karakter anak yang suka melanggar peraturan ditunjukkan dengan baju Dilan yang tidak dimasukkan ke dalam celana. Sedangkan Milea tampak sebagai siswa yang rapi dan kalem yang ditunjukkan dengan baju seragamnya dimasukkan secara rapi dan rambutnya diurai panjang. 3). Implicit Meaning

Makna secara implisit tampak pada Gambar 2, di mana melakukan pendekatan kepada seseorang itu tidak harus semata dengan memperkenalkan diri atau meminta nomor telepon, tetapi ada cara lain yang yang justru akan berkesan, yakni meramal seperti yang dilakukan oleh tokoh Dilan.

4). Symptomatic Meaning

Kejadian pada Gambar 2 pun relevan dengan kejadian nyata pada anakanak remaja SMA dulu ataupun sekarang. Pendekatan terhadap lawan jenis untuk menarik perhatian. Sutradara memainkan plot film dengan unik, karena tidak dapat dibaca oleh penonton, tetapi mampu memenuhi ekspektasi (harapan-harapan) penonton. Gambar 2 menunjukkan bahwa 
saat Milea jalan sendiri menuju ke sekolah akan ada yang menghampirinya. Dan harapan itu terpenuhi atau tujuan sutradara dapat dibaca di shot selanjutnya, yakni Dilan menghampiri Milea menggunakan motornya. Hal itu dapat dimaknai bahwa Dilan melakukan pendekatan kepada Milea.

\section{SIMPULAN}

Berdasarkan analisis yang telah dilakukan pada adegan pengantar film Dilan 1990 dapat disimpulkan bahwa film ini menceritakan kisah percintaan remaja SMA di tahun 1990. Penceritaannya memiliki konsep bentuk yang sesuai dengan teori David Bordwell \& Kristin Thompson. Sehingga, tidak mengherankan jika film Dilan 1990 mampu menarik perhatian dan minat penonton untuk melihatnya. Hal ini dikarenakan bentuk dan sistem yang bekerja pada film sangat kompleks. Elemen-elemen seperti narasi, audio, dan visual yang dibangun memiliki keterkaitan satu dengan yang lain, sehingga dapat melibatkan atau membangun emosi penonton. Kepiawaian sutradara tampak pada cara memainkan plot cerita, dan menstimulus ekspektasi, dan pemenuhan harapan-harapan penonton melalui setiap adegan.

\section{DAFTAR ACUAN}

Bordwell, David dan Kristin Thompson. (2008). Film Art: An Introduction. The McGraw-Hill Companies Inc. Edisi kedelapan.
Eisenstein, Sergei. (1957). Film Form and The Film Sense, New York: Meridian Books.

Muhammad, Mastura. (2006). Prinsip dan Konsep Bentuk Filem Nujum Pak Belalang. Jurnal Skrin Malaysia. 3, 171-188. ISSN 1823-1020.

Murfianti, Fitri. (2018). Meme di Era Digital dan Budaya Siber. Laporan Penelitian ISI Surakarta. http://repository.isiska.ac.id/3359/1/MEME\%20DI\%20E RA\%20DIGITAL\%20DAN\%20BUDA YA\%20SIBER_Fitri\%20Murfianti.pdf

Patawari, Muhammad Yunus. (2019). Stylometry: Statistical Approach Into Film Style. CAPTURE: Jurnal Seni Media Rekam Vol.10 No.2. ISSN 2338-428X. DOI: 10.33153/capture.v10i2.2451. https://jurnal.isiska.ac.id/index.php/capture/article/vi ew/2451/2289

Yulistara, Arina. (2018). 10 Film Indonesia Terlaris, Dilan Teratas di 2018. https://www.cnbcindonesia.com/life style/20180409194021-3310330/10-film-indonesia-terlarisdilan-teratas-di-2018 diakses pada tanggal 23 April 2021 pukul 09.17 WIB.

Publisher:

Jurusan Seni Media Rekam, Fakultas Seni Rupa dan Desain, Institut Seni Indonesia (ISI) Surakarta.

Available online at:

https://jurnal.isi-ska.ac.id/index.php/capture

How to Cite:

Rohma, Naafi Nur. (2021). Concept of Form in The Film Dilan 1990. CAPTURE: Jurnal Seni Media Rekam, 12(2), 117-131. 